\title{
Discussion on "Experimental Deformation of Opalinus Clay at Elevated Temperature and Pressure Conditions: Mechanical Properties and the Influence of Rock Fabric" of Schuster, V., Rybacki, E., Bonnelye, A., Herrmann, J., Schleicher, A.M., Dresen, G.
}

\author{
Eleonora Crisci ${ }^{1}$ (1) $\cdot$ Alessio Ferrari ${ }^{1,2} \cdot$ Lyesse Laloui $^{1}$
}

Received: 4 July 2021 / Accepted: 19 September 2021 / Published online: 5 October 2021

(c) The Author(s) 2021

\begin{abstract}
The testing procedure and results on saturated samples of Opalinus Clay in the work of Schuster et al. (Rock Mech Rock Eng https://doi.org/10.1007/s00603-021-02474-3, 2021) were conducted and presented using strain rates two to four orders of magnitudes higher than the rates needed to allow pore pressure equilibrium in the material, both in drained and undrained conditions. This leads to an erroneous estimation of the mechanical properties in saturated conditions. We discuss this aspect in the context of shale testing. We also discuss the effect of drying-induced fissuring on the mechanical properties of geomaterials tested in dry conditions.
\end{abstract}

Keywords Clay rock $\cdot$ Opalinus Clay $\cdot$ Testing procedure $\cdot$ Pore pressure generation $\cdot$ Strain rate $\cdot$ Rate-dependent mechanical behaviour $\cdot$ Desiccation cracks $\cdot$ Micro-fissuring $\cdot$ Shale

\section{Introduction}

Shales are geomaterials that share features of soft rocks (e.g. relatively high strength and stiffness and low porosity compared to clays) and features of overconsolidated clays (e.g. low permeability). As such, the presence of the pore water, the degree of saturation and the pore pressure generation during mechanical load assume crucial importance. Sound testing procedures for shale have been built in recent years. In this note, we examine the recent results on wet samples by Schuster et al. (2021) (Sects. 3.1.1, 3.1.5), we discuss the inhomogeneous pore pressure generation, in both drained and undrained shearing conditions, and its potential impact on the obtained mechanical properties, and the potential effect of drying-induced fissuring on the mechanical properties of samples (Sects. 2.1, 3.1.2).

Eleonora Crisci

eleonora.crisci@epfl.ch

1 Laboratory for Soil Mechanics (LMS), EPFL-ENAC-LMS, Ecole Polytechnique Fédérale de Lausanne (EPFL), Station 18, 1015 Lausanne, Switzerland

2 Department of Engineering, Università Degli Studi di Palermo, Viale Delle Scienze, Ed. 8, 90128 Palermo, Italy

\section{Pore Pressure Generation}

Saturating and testing low porosity and low permeability geomaterials can be challenging and time-consuming. An efficient way to do this has been demonstrated to be by applying sufficient stress to the sample to negate the capillary tension and bring the pore pressure up to a positive value (Ewy 2018; Horsrud et al. 1998; Steiger and Leung 1991). Ewy (2018) presented examples of this approach and illustrated how pre-conditioning samples to high relative humidity (RH) make this a convenient method for shale testing. Giger et al. (2018) and Minardi et al. (2019, 2020) successfully adopted this procedure for Opalinus Clay (sandy and shaly facies). The same technique was applied by Schuster et al. (2021) to test wet samples of Opalinus Clay.

By applying confining stresses in the order of tens of $\mathrm{MPa}$ to pre-conditioned shale samples (with $\mathrm{RH}>90 \%$ ), positive pore pressure, in the order of several MPa is developed (Ewy 2018; Giger et al. 2018; Minardi et al. 2020). For the saturated samples in the work of Schuster et al. (2021) nonnegligible pore overpressures must have been developed as isotropic confining pressure of $50 \mathrm{MPa}$ was applied.

Furthermore, during the shearing phase, the effective stress paths that the samples experienced would strongly 
depend on the pore pressure developed at the end of the isotropic compression, and its evolution throughout the deviatoric loading: the peak strength for each sample should be evaluated by considering the achieved effective confinement. The pore overpressure generated during shearing is driven by the sample anisotropy (Minardi et al. 2020), composition and porosity (Crisci et al. 2021; Minardi et al. 2019), significantly altering the effective stress at peak deviatoric stress: P-samples develop lower pore pressure during shearing, i.e. higher mean effective stress, with respect to S-samples. In Schuster et al. (2021), while comparing the results between $\mathrm{P}$ - and S-samples in terms of total confining stress, the two seem to show a remarkable difference in terms of peak strength, while the discrepancy is reduced when effective stress is considered.

Data from Minardi et al. (2020) showed that the failure envelope for P-samples had an intercept about $70 \%$ higher than the S-samples, while the shear strength angle remains substantially unchanged. Results on Opalinus Clay samples sourced from deep boreholes, and including a wide range of compositions, showed a similar trend (Crisci et al. 2020).

\section{Strain Rate}

The strain rate at which a sample is sheared impacts the pore water redistribution and pressure generation (Head and Epps 2014; Giger et al. 2018). Measurements of the pore pressure evolution would allow computing the effective stress path during each test. Analysing the results in terms of effective stress allows reconciling the apparent differences among samples tested in undrained conditions.

For a saturated sample, the consolidation coefficient derived from isotropic loading can be used to estimate the appropriate strain rate to apply in drained or undrained conditions. In both cases, the choice of the strain rate has to ensure that the pore pressure is homogenous within the sample, either homogeneously increasing within the specimen (undrained) or in equilibrium with the imposed boundary condition (drained).

In the work of Giger et al. (2018), it is shown that for undrained testing, a strain rate one order of magnitude greater than the one theoretically appropriate for pore pressure equilibration led to an apparent strength increase of 15-20\%. A strain rate two orders of magnitude faster caused an overestimation of shear strength of $40 \%$ and Poisson's ratio underestimation of $70 \%$.

When an inappropriately fast strain rate is applied, pore pressure is generated non-homogenously within the sample (i.e. the pore pressure increment may be localized). The resulting mechanical parameters are therefore due to the effect of a non-homogenous effective stress field within the sample, which may depend also on its specific structure. The so-obtained parameters cannot be considered as representative of the geomaterial properties.

A consolidation coefficient of $0.002 \mathrm{~mm}^{2} / \mathrm{s}$ is reported in Schuster et al. (2021), which is broadly in line with measurements on Opalinus Clay obtained in oedometric or triaxial conditions in other works (Crisci et al. 2019; Ferrari et al. 2016; Minardi et al. 2019). Computing the strain rate for drained and undrained shearing (Head and Epps 2014), values in the order of magnitude $10^{-8} \mathrm{1} / \mathrm{s}$ and $10^{-7} \mathrm{1} / \mathrm{s}$ would be obtained, respectively. The most suitable rates depend on the sample dimensions and drainage (e.g. radial drainage, at the ends of the specimen). These rates are two to four orders of magnitudes slower than those adopted for saturated samples in drained and undrained conditions in Schuster et al. (2021). In Schuster et al. (2021) the use of an inappropriately fast strain rate is mentioned for drained tests; however, also the undrained results have to be considered as strongly dependent on the incorrect strain rate adopted and the consequent inhomogeneous pore pressure development.

In addition, the works of Favero et al. (2018), Giger et al. (2018), and Minardi et al. (2019, 2020) show consistency between the drained and undrained results once the appropriate strain rates are adopted: analysing the results in terms of effective stress, it is clear that failure envelope is single for each geomaterial, independently from the drainage conditions used for testing. This is in line with the expected response for overconsolidated clays.

\section{Sample Preparation}

Except for the wet samples, in Schuster et al. (2021), samples were dried before mechanical testing. Sample drying causes shrinkage deformation and eventually cracking. This phenomenon is known in clays, but also shales and claystone (Ewy 2014; Minardi et al. 2016; Pham et al. 2007). Fissures will most likely appear along bedding planes, compromising their cementation. In Z-samples, this can result in a loss of strength, which would be shown by limited peak-to-postpeak strength reduction: the shear strength along the failure surface, sub-parallel to the bedding direction in Z-samples, will be solely governed by the friction developed on the surface, which decreases with the increase in shear strains. The limited post-peak strength reduction observed in Schuster et al. (2021) may be profoundly affected by the dryinginduced cracking.

Funding Open Access funding provided by EPFL Lausanne. 
Open Access This article is licensed under a Creative Commons Attribution 4.0 International License, which permits use, sharing, adaptation, distribution and reproduction in any medium or format, as long as you give appropriate credit to the original author(s) and the source, provide a link to the Creative Commons licence, and indicate if changes were made. The images or other third party material in this article are included in the article's Creative Commons licence, unless indicated otherwise in a credit line to the material. If material is not included in the article's Creative Commons licence and your intended use is not permitted by statutory regulation or exceeds the permitted use, you will need to obtain permission directly from the copyright holder. To view a copy of this licence, visit http://creativecommons.org/licenses/by/4.0/.

\section{References}

Crisci E, Ferrari A, Giger SB, Laloui L (2019) Hydro-mechanical behaviour of shallow Opalinus Clay shale. Eng Geol 251:214227. https://doi.org/10.1016/j.enggeo.2019.01.016

Crisci E, Giger SB, Laloui L (2020) TBO Bülach-1-1: data report dossier IX - rock-mechanical and geomechanical laboratory testing (No. Arbeitsbericht NAB 20-08/IX). https://www.nagra.ch/en/cat/ publikationen/arbeitsberichte-nabs/nabs-2020-e/downloadcentre. htm. Link functionality checked on 30 June 2021

Crisci E, Ferrari A, Giger SB, Laloui L (2021) Effect of the mineralogical composition on the elastoplastic hydromechanical response of Opalinus Clay shale. Int J Rock Mech Min Sci 143:104747. https://doi.org/10.1016/j.ijrmms.2021.104747

Ewy RT (2014) Shale swelling/shrinkage and water content change due to imposed suction and due to direct brine contact. Acta Geotech 9:869-886. https://doi.org/10.1007/s11440-013-0297-5

Ewy RT (2018) Practical approaches for addressing shale testing challenges associated with permeability, capillarity and brine interactions. In: Themed issue on selected papers from the international workshop on advances in laboratory testing and modelling of soils and shales, Geomech Energy Environ, vol 14, pp 3-15. https://doi. org/10.1016/j.gete.2018.01.001

Favero V, Ferrari A, Laloui L (2018) Anisotropic behaviour of Opalinus Clay through consolidated and drained triaxial testing in saturated conditions. Rock Mech Rock Eng 51:1305-1319. https:// doi.org/10.1007/s00603-017-1398-5

Ferrari A, Favero V, Laloui L (2016) One-dimensional compression and consolidation of shales. Int J Rock Mech Min Sci 88:286-300. https://doi.org/10.1016/j.ijrmms.2016.07.030
Giger SB, Ewy RT, Favero V, Stankovic R, Keller LM (2018) Consolidated-undrained triaxial testing of Opalinus Clay: results and method validation. In: Themed issue on selected papers from the international workshop on advances in laboratory testing and modelling of soils and shales, Geomech Energy Environ, vol 14, pp 16-28. https://doi.org/10.1016/j.gete.2018.01.003

Head KH, Epps RJ (2014) Manual of soil laboratory testing, vol 3, 3rd edn. Whittles Publishing, Dunbeath

Horsrud P, Sønstebø EF, Bøe R (1998) Mechanical and petrophysical properties of North Sea shales. Int J Rock Mech Min Sci 35:1009-1020

Minardi A, Crisci E, Ferrari A, Laloui L (2016) Anisotropic volumetric behaviour of Opalinus clay shale upon suction variation. Géotech Lett 6:1-5. https://doi.org/10.1680/jgele.16.00023

Minardi A, Ferrari A, Laloui L (2019) Benchmark study on triaxial testing of Opalinus Clay: analysis and comparative evaluation of tests results. Nagra Arbeitsbericht NAB 19-018. Nagra, Wettingen

Minardi A, Giger SB, Ewy RT, Stankovic R, Stenebråten J, Soldal M, Rosone M, Ferrari A, Laloui L (2020) Benchmark study of undrained triaxial testing of Opalinus Clay shale: results and implications for robust testing. Geomech Energy Environ. https://doi.org/ 10.1016/j.gete.2020.100210

Pham QT, Vales F, Malinsky L, Nguyen Minh D, Gharbi H (2007) Effects of desaturation-resaturation on mudstone. Phys Chem Earth Parts ABC 32:646-655. https://doi.org/10.1016/j.pce.2006. 03.012

Schuster V, Rybacki E, Bonnelye A, Herrmann J, Schleicher AM, Dresen G (2021) Experimental deformation of Opalinus Clay at elevated temperature and pressure conditions: mechanical properties and the influence of rock fabric. Rock Mech Rock Eng. https:// doi.org/10.1007/s00603-021-02474-3

Steiger RP, Leung PK (1991) Consolidated undrained triaxial test procedure for shales. Presented at the The 32nd U.S. symposium on rock mechanics (USRMS)

Publisher's Note Springer Nature remains neutral with regard to jurisdictional claims in published maps and institutional affiliations. 